\title{
FUZZY-PID CONTROLLER FOR COUPLED TWO TANK INTERACTING SYSTEM
}

\author{
K PRAVALLIKA ${ }^{1} \&$ G VAMSI KRISHNA ${ }^{2}$ \\ ${ }^{I} P G$ Student, Department of Electronics and Instrumentation Engineering, \\ VNR Vignana Jyothi Institute of Engineering and Technology, Hyderabad, India \\ ${ }^{2}$ Assistant Professor, Department of Electronics and Instrumentation Engineering, \\ VNR Vignana Jyothi Institute of Engineering and Technology, Hyderabad, India
}

\begin{abstract}
The liquid level controlling is an interesting aspect in control engineering. Coupled tanks are widely used in various industries for intermediate storage and have various inputs and outputs. The control action has to be fast and also accurate. The manner of controlling a MIMO is clashing with the SISO. In two tank coupled interacting system control strategy is not like a SISO. A conventional PID sometime has constraints like overshoot, stability. Designing of mathematical model for various two tank interacting system is facilitated for the simulation study. In this paper intends to give a detail simulation study of Fuzzy PID controller to control various 2 tank systems. The designed Fuzzy PID is compared to the conventional PID controller. The transient responses of these systems are studied for the slightest disturbance given to the control system. Simulation of the controller is done in Matlab which is shown and described. KEYWORDS: Coupled interacting system, Fuzzy-PID controller, PID controller, Mathematical modelling \& Transient response
\end{abstract}

Received: Jun 06, 2020; Accepted: Jun 26, 2020; Published: Aug 21, 2020; Paper Id.: IJMPERDJUN2020839

\section{INTRODUCTION}

The liquid tanks are typically used as an intermediate storage for liquid storage which are being transferred amongst the varied process in the plant of a complex control system. The main restriction is that the physical attribute i.e. height of the tank to avoid the overflows and also to avoid hazards within the plant. The objective of paper is to take care of the liquid level within certain limits. The desired height is understood as set point. The input variable is that the inflow into the tank which is additionally called as manipulated variable and also considered because the disturbance.

In process control, Water level control of coupled tank interacting system is a very difficult; because of the system nonlinearities and uncertainties [2]. Due to inaccuracy the industries are depriving the yields. The level controlling is an interesting aspect in control system engineering. Several controller algorithms are in use. Coupled tanks are widely used in various industries and have various inputs. Many situations in the industries makes in control action to be speed and also accurate. This makes it necessity to employ a method to effectively control the level of the tank.

Many methods are available to regulate the level of the tank for coupled tanks such as PI, PID, Fuzzy PID, neural network method. Fuzzy controller gives a mortal like intrusion to the control strategy with preciseness. The coupled tanks have multiple inputs and multiple outputs. The controlling of a Multi Input Multi Output conflicts with single input single output in many ways because of various parameters and the complexity and complex 
interconnectivity[1]. with this a conventional PID has drawbacks overshoots, settling time. The fuzzy controller combines different internal components like fuzzification, defuzzification and fuzzy rule base.

The primitive objective of this project is to compare the input in the fuzzy rule base and according manipulate the input and regulate the output with the, if and then rules. This makes it effective with the precise output. It is robust, easily controllable strategy it is capable of realizing multi input and numerous outputs. Though the traditional PID attributes an easy arithmetic, good dynamics and steady performance. But it features overshoot oscillations[1]. This paper is a blend of PID and fuzzy control for controller action. The performance of the fuzzy PID is correlated with the traditional PID. The fuzzy controller realizes the action by error and alter in error. The fuzzy controller uses feedback signal because the input and address them via fuzzy rule. If the input is convincing then the output is within the sort of correlated parameters of $K_{p}, K_{i}, K_{d}$. The improved parameters are given to the PID controller and therefore the output of the PID control is that the improvised control signal. The fuzzy PID controller accommodates both excellence of PID control and fuzzy control like fast response, slight steady state error and suits for nonlinear systems.

In this paper fuzzy rule is predicated on Mamdani fuzzy technique which improves the performance of the controller SISO system has one manipulated variable that directly controls the output. But during a MIMO system there are more input and output it makes the system complex and hard for controlling[6]. Because there'll be influence manipulated of the opposite control loops. Hence the traditional controllers used for the SISO system doesn't effectively applied to the MIMO system. paper.

In this paper a transient signal is given to the system to record the transient response of various Coupled interacting system.

\section{METHOD}

\section{Mathematical Modelling of Coupled Interacting System}

Figure 1 is an example for a SISO system which is a single tank system which features a single inlet and single outlet valve and the objective is to constrain the apex of one tank. the volume of water within the tank is proportional to height of the tank. the height of the tank is proportional to inflow of the fluid to the outflow of the tank through the valve.

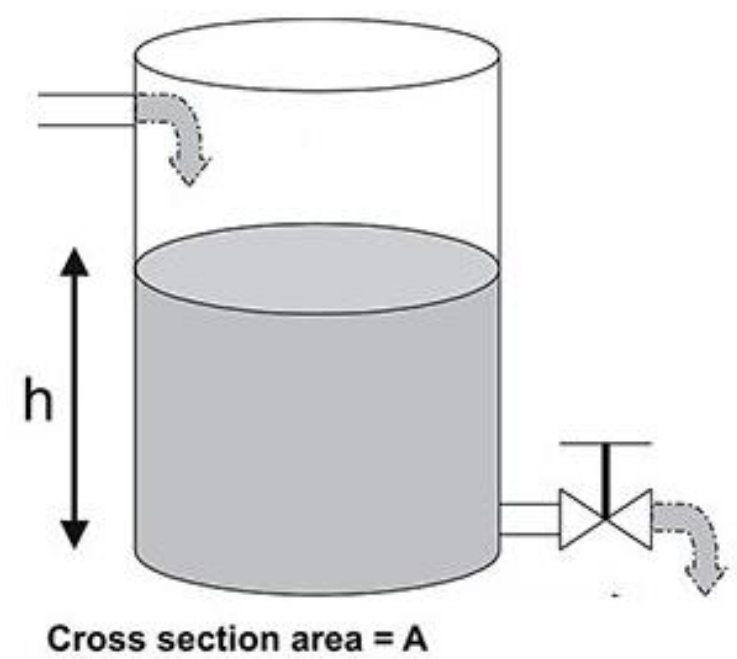

Figure 1: Single Input Single Output Water Tank System 
As stated by mass-balance equation, the first order equation for the tank is written as

$$
\frac{d V o l}{d t}=A \frac{d H}{d t}=b V-a \sqrt{H}
$$

Here $\mathrm{V}$ is the volume of liquid within tank, A is that the area cross-sectional of the tank, "b" is a constant associated with the flow into the tank, and "a" is the constant associated with the outflow of a tank. The equation describes the maximum height of liquid, "H", as a function of time, the distinction between flow into and out of the tank. The above equation states the celerity of change of flow inlet to the haste of change of the outflow.

\section{The Coupled Interacting System}

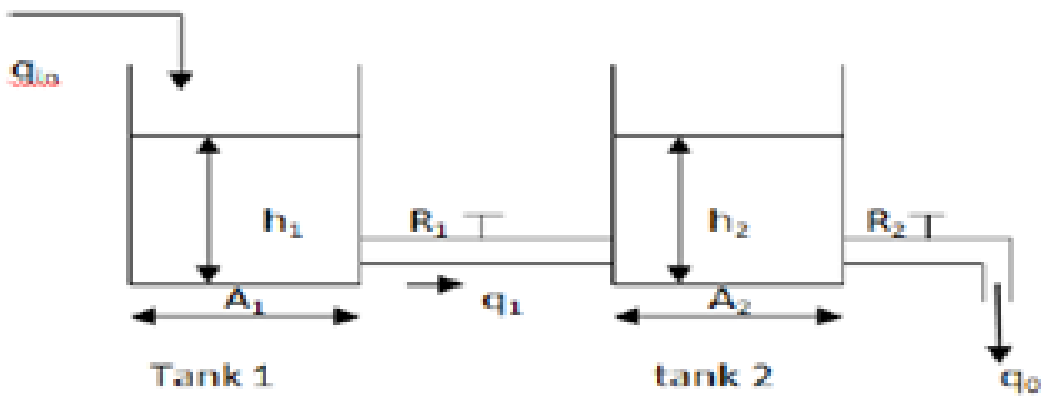

Figure 2: Two Tank Interacting System

The intermediate relation between different control loop is give in figure 3. This shows how the control loops are interrelated. figure shows the multiple input and multiple output.

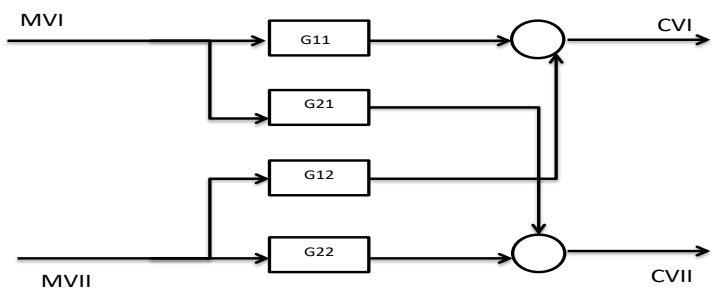

Figure 3: Mathematical Modelling of Coupled Tank Interacting System.

From the on top of figure MVI and MVII are the two manipulated variables going into the tank, CVI and CVII are the two controlled variables going out of the tank and G11 represents the forward path dynamics between MVI and CVI. G22 represents how CVII responds to a transmutation in MVII. Interaction effects are modelled utilizing transfer function G21 and G12. G21 describes how CVII changes with reference to a vicissitude in MVI[1]. G21 describes how CVI changes with reference to a transmutation in MVII.

From the figure 2 the given below. The below equations are for system 1

$$
\begin{aligned}
& \mathrm{A}_{1}=\text { Inner surface area of tank 1, } \\
& \mathrm{h}_{1}=\text { Height of the water level in tank } 1, \quad \mathrm{~A}_{2}=\text { Inner surface area of tank } 2 \\
& \text { For TANK1, we have } \\
& \quad A_{1} \frac{d h_{1}(t)}{d t}=f_{1}(t)-\frac{h_{1}(t)-h_{2}(t)}{R_{1}}-\frac{h_{1}(t)}{R_{2}}
\end{aligned}
$$


For TANK2, we have

$$
A 2 \frac{d h 2(t)}{d t}=f_{2}(t)+\frac{h 1(t)-h 2(t)}{R 1}-\frac{h 2(t)}{R 3}
$$

then for two tank system considered for experimenting, we have $A_{1}=A_{2}=0.016 m^{2}, R_{1}=R_{2}=R_{3}=$ Discharge Coefficient $\left(\mathrm{sec} / \mathrm{m}^{2}\right)=4.212 \mathrm{~mm} / \mathrm{LPH}=15652 \mathrm{sec} / \mathrm{m}^{2}$.

Substituting the parameters in above equations we get

$$
\begin{aligned}
& \frac{d h_{1}}{d t}=59.1715 f_{1}-0.0076095 h_{1}+0.0038047 h_{2} \\
& \frac{d h_{2}}{d t}=59.1715 f_{2}+0.0038047 h_{1}-0.0076095 h_{2}
\end{aligned}
$$

The above equations are now in state space form, and in matrix form they can be written as follow,

$$
\frac{\mathrm{dh}}{\mathrm{dt}}=\mathrm{AH}+\mathrm{BF}
$$

Where

$$
\begin{aligned}
& A=\left[\begin{array}{cc}
-0.0076095 & 0.0038047 \\
0.0038047 & -0.0076095
\end{array}\right], \quad B=\left[\begin{array}{cc}
59.1715 & 0 \\
0 & 59.1715
\end{array}\right] \\
& h=\left[\begin{array}{l}
h_{1} \\
h_{2}
\end{array}\right] \quad f=\left[\begin{array}{l}
f_{1} \\
f_{2}
\end{array}\right]
\end{aligned}
$$

By applying state space modelling for the above equations

$$
\left.(S I-A)^{-1}=\left[\begin{array}{ll}
S & 0 \\
0 & S
\end{array}\right]-\left[\begin{array}{cc}
\left(A_{1} R_{1} R_{2} S\right)+R_{1}+R_{2} & -R_{2} \\
-R_{3} & A_{2} R_{1} R_{3} S+R_{2}+R_{3}
\end{array}\right]\right]^{-1}
$$

These are the transfer functions for Coupled tank interacting Systems

$$
\begin{array}{rlrl}
\mathrm{G}_{11} & =\frac{S+0.0076095}{S^{2}+0.015219 S+0.000434287} & \mathrm{G}_{12} & =\frac{0.0038047}{S^{2}+0.015219 S+0.000434287} \\
\mathrm{G}_{21}=\frac{0.0038047}{S^{2}+0.015219 S+0.000434287} & \mathrm{G}_{22} & =\frac{S+0.0076095}{S^{2}+0.015219 S+0.000434287}
\end{array}
$$

These are the transfer functions for Coupled tank interacting System $2 \mathrm{~A}_{1}=\mathrm{A}_{2}=0.015 \mathrm{~m}^{2}, \mathrm{R}_{1}=\mathrm{R}_{2}=\mathrm{R}_{3}=$ Discharge Coefficient $\left(\mathrm{sec} / \mathrm{m}^{2}\right)=642 \mathrm{sec} / \mathrm{m}^{2}$.

$$
\begin{aligned}
\mathrm{G}_{11} & =\frac{s+0.00312}{s^{2}+0.00624 S+0.0000073} & \mathrm{G}_{12} & =\frac{0.00156}{s^{2}+0.00624 S+0.0000073} \\
\mathrm{G}_{21} & =\frac{0.00156}{S^{2}+0.00624 S+0.0000073} & \mathrm{G}_{22} & =\frac{s+0.00312}{S^{2}+0.00624 S+0.0000073}
\end{aligned}
$$

These are the transfer functions for Coupled tank interacting System 3 when the values of $A_{1}=A_{2}=0.00755 \mathrm{~m}^{2}, R_{1}$ $=\mathrm{R}_{2}=\mathrm{R}_{3}=$ Discharge Coefficient $\left(\mathrm{sec} / \mathrm{m}^{2}\right)=4.379 \mathrm{sec} / \mathrm{m}^{2}$.

$$
\begin{aligned}
\mathrm{G}_{11} & =\frac{S+0.4567}{S^{2}+0.9134 S+0.1564} & \mathrm{G}_{12} & =\frac{0.2284}{S^{2}+0.9134 S+0.1564} \\
\mathrm{G}_{21} & =\frac{0.2284}{S^{2}+0.9134 S+0.1564} & \mathrm{G}_{22} & =\frac{S+0.4567}{S^{2}+0.9134 S+0.1564}
\end{aligned}
$$


The control strategy of a fuzzy PID is done by utilizing the error and the transmutation within the error because the input and the output because the control signal for the PID.

The proposed system is predicated on Mamdani fuzzy system it realizes the desideratum of control by taking the feedback because the input. during this learning scheme a standard feedback controller is employed as mundane feedback controller which assurance the ecumenical a symbolic stability during a compact space and as an inverse reference model replication of the controller object.

The fuzzy controller output is within the remotely three parameters of PID that's $K_{p}, K_{i}$ and $K_{d}$ when tuned utilizing symbolic logic controller it's termed as self-tuning fuzzy-PID controller. Tuning of PID controller parameters can't be felicitously tuned manually. Consequently, the PID parameters should transmute by its own at a concrete time within particular limit.

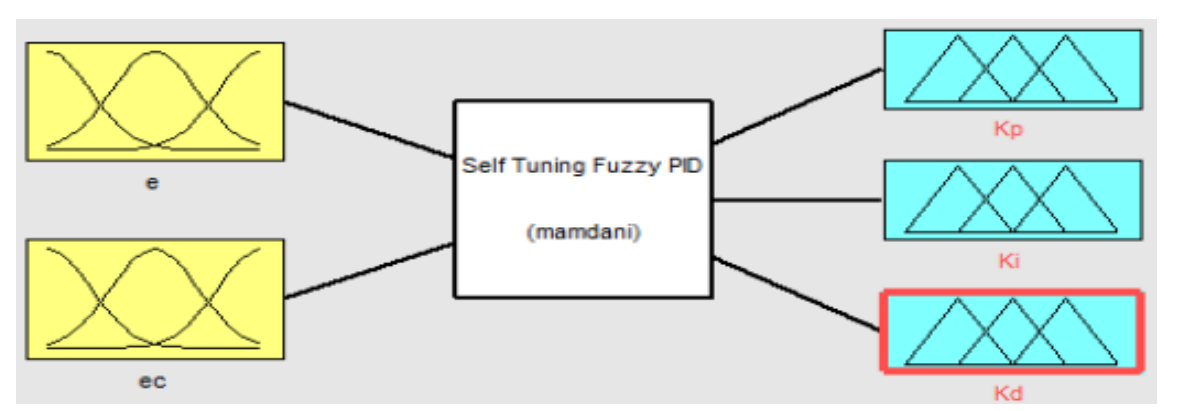

Figure 4: Fuzzy Logic Editor

The main key in fuzzy-PID controller is PID, which implements the concept of fuzzy if-then rules and defuzzification of the output variable is consummated to automatically transmute the PID parameters. Error and rate of vicissitude in error is calculated and alimented to the controller as shown in fig.5. These are utilized because the input variables to the fuzzy controller, and ergo the output (defuzzified) variables are the parameters of PID control, those are $\Delta \mathrm{K}_{\mathrm{p}}, \Delta \mathrm{K}_{\mathrm{i}}$ and $\Delta \mathrm{K}_{\mathrm{d}}$. Here e denotes the error in liquid level; $\mathrm{e}_{\mathrm{c}}$ denotes rate of transmutation in error in process.

\section{Assembling of self-tuning Fuzzy PID Controller}

The fuzzy controller works rudimentally by range of membership functions decided the outputs for inputs. Generally, the range of input to the fuzzy controller goes from extreme negative to extreme positive, while that of output is customarily positive[3]. The fuzzy rules are then composed which keep updating consistent with the error signals and the vicissitude in error signal. The aggregation method used here is max-min. Defuzzification method used is centroid.

In FIS block the 2 inputs are: error and rate of change in error $\mathrm{e}_{\mathrm{c}}$, and three outputs for every PID controller parameters $\mathrm{Kp}$ ', Ki' and K'd respectively. Two Mamdani marginally fuzzy controllers should be used discretely to regulate the manipulated are the particular level beginning from each tank in order that the controlled signal is passed to every process tanks discretely[1].

The parameters of PID controller $\mathrm{K}_{\mathrm{p}}, \mathrm{K}_{\mathrm{i}}$ and $\mathrm{K}_{\mathrm{d}}$ are given within the range of $\mathrm{Kp}_{\min }$ to $\mathrm{Kp}_{\max }, \mathrm{Ki}_{\min }$ to $\mathrm{Ki}_{\max }, \mathrm{Kd}_{\min }$ to $\mathrm{Kd}_{\max }$. fortified by the rule base, probability of error within the system and simulation results, the ranges of PID parameters are decided. The range of authentic parameters without fuzzy involution are, $\mathrm{Kp} \in(3,10), \mathrm{Ki} \in(1.5,2.5)$ and $\mathrm{Kd} \in(3,4.5)$. Hence the output range of fuzzy control signal are often manipulated between (0-1). The mathematical equation for PID parameters as shown below: 


$$
K_{p}=7 K_{p}^{\prime}+3, \quad K_{i}=K_{i}{ }^{\prime}+1.5 \text { and } \quad K_{d}=K_{d}{ }^{\prime}+0.1
$$

Table 1: Error Change of Error Fuzzy System Rules

\begin{tabular}{|c|c|c|c|c|c|}
\hline De/e & NB & NS & ZE & PS & PM \\
\hline NB & S & S & MS & MS & M \\
\hline NS & S & MS & MS & M & MB \\
\hline ZE & MS & MS & M & MB & MB \\
\hline PS & MS & M & MB & MB & B \\
\hline PB & M & MB & MB & B & B \\
\hline
\end{tabular}

Table 2: Fuzzy Systems Rules

\begin{tabular}{|c|c|}
\hline & les (IF-THEN rules) - relationshi \\
\hline$\bullet$ & if (e is NB) and ( $e_{c}$ is NB) then ( $k_{p}$ is $\left.S\right)\left(k_{i}\right.$ is $\left.S\right)\left(k_{d}\right.$ is $\left.S\right)$ \\
\hline$\bullet$ & if (e is NS) and ( $e_{c}$ is NB) then $\left(k_{p}\right.$ is $\left.S\right)\left(k_{i}\right.$ is $\left.S\right)\left(k_{d}\right.$ is $\left.S\right)$ \\
\hline$\bullet$ & 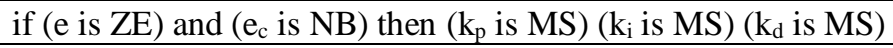 \\
\hline$\bullet$ & 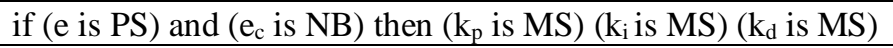 \\
\hline & if (e is $P B)$ and ( $e_{c}$ is NB) then $\left(k_{p}\right.$ is $\left.M\right)\left(k_{i}\right.$ is $\left.M\right)\left(k_{d}\right.$ is $\left.M\right)$ \\
\hline
\end{tabular}

\section{RESULTS AND DISCUSSIONS}

\section{Simulink Model of Coupled Tank comparing PID and Fuzzy-PID}

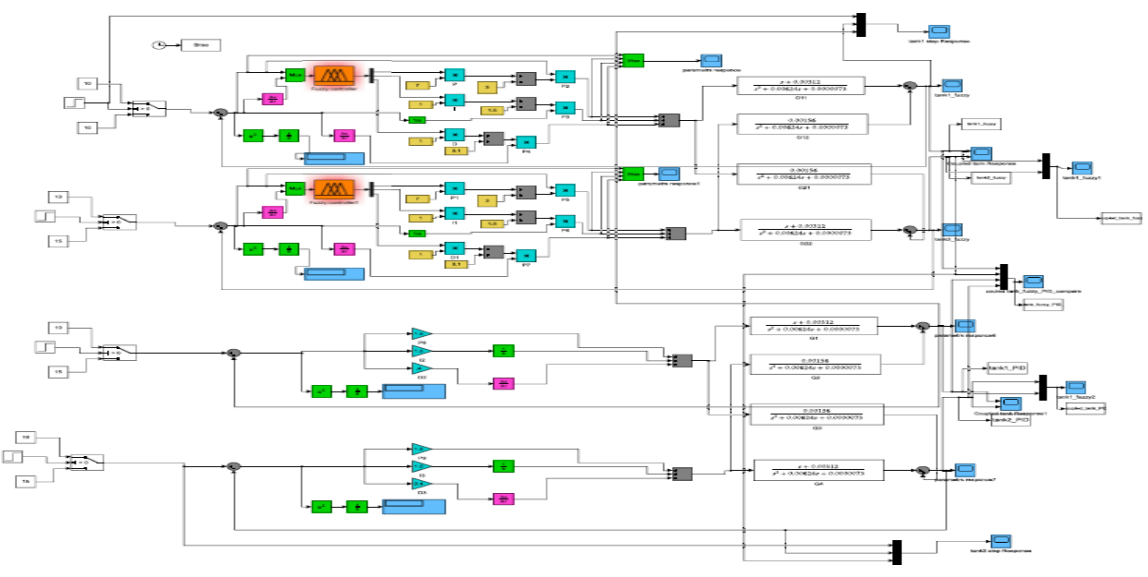

Figure 5: MATLAB simulation of coupled tank comparing PID and Fuzzy-PID

Fuzzy logic controller sends control signals to the PID controller for transmuting the $\mathrm{K}_{\mathrm{p}}, \mathrm{K}_{\mathrm{i}}$ and $\mathrm{K}_{\mathrm{d}}$ parameters. It is often visually perceived here that the replication of tank fortified fuzzy-PID has less settling time but that of PID

\section{Simulation Results}

Integral square error method shows the comparison between the fuzzy-PID and PID controller. Self-tuning fuzzy-PID controller is best than classical PID controller. The replications of the proposed control design look gratified. However, the proposed control must be developed on genuine hardware by including disturbance and any others nonlinearity and uncertainties within the design with sundry frequencies in reference input signals.

\section{Transient Response Analysis}

For evaluating the transient response analysis, we have considered four cases and studied their behaviour analysis in all the 
3 systems discussed above. The 4 cases considered are as follows

Table 3: different cases for studing their behaviour analysis

\begin{tabular}{|l|l|l|}
\hline & Tank 1 & Tank 2 \\
\hline Case -1 & Level is increased from $10 \mathrm{~cm}$ to $15 \mathrm{~cm}$ at $15 \mathrm{sec}$ & Level is increased from $20 \mathrm{~cm}$ to $25 \mathrm{~cm}$ at $20 \mathrm{sec}$ \\
\hline Case $-\mathbf{2}$ & Level is increased from $10 \mathrm{~cm}$ to $15 \mathrm{~cm}$ at $15 \mathrm{sec}$ & Level is decreased from $25 \mathrm{~cm}$ to $20 \mathrm{~cm}$ at $20 \mathrm{sec}$ \\
\hline Case $-\mathbf{3}$ & Level is decreased from $15 \mathrm{~cm}$ to $10 \mathrm{~cm}$ at $15 \mathrm{sec}$ & Level is increased from $20 \mathrm{~cm}$ to $25 \mathrm{~cm}$ at $20 \mathrm{sec}$ \\
\hline Case $-\mathbf{4}$ & Level is decreased from $15 \mathrm{~cm}$ to $10 \mathrm{~cm}$ at $15 \mathrm{sec}$ & Level is decreased from $25 \mathrm{~cm}$ to $20 \mathrm{~cm}$ at $20 \mathrm{sec}$ \\
\hline
\end{tabular}

\section{Transient Response Analysis for System 1:}

\section{Case 1:}

For studying the behaviour analysis Let's consider a case where the level of the tank 1 is increased from 10-15 at 15 seconds and level of tank 2 is $20-25$ at 20seconds. The behavioural graph is given below.

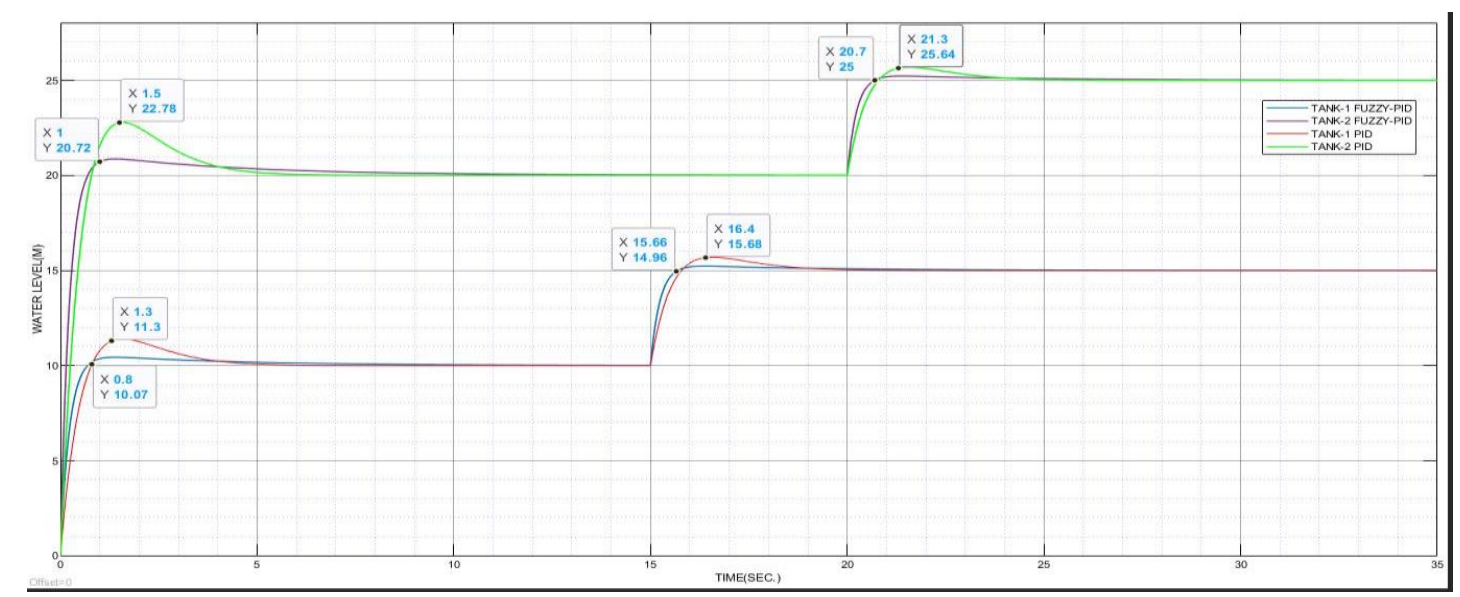

Figure 6: Output responses of coupled tanks for PID and Fuzzy-PID for case1

\section{Case 2:}

For studying the behaviour analysis Let's consider another case where the level of the tank 1 is increased from10-15 at 15 seconds and level of tank 2 is decreased from $25-20$ at 20 seconds

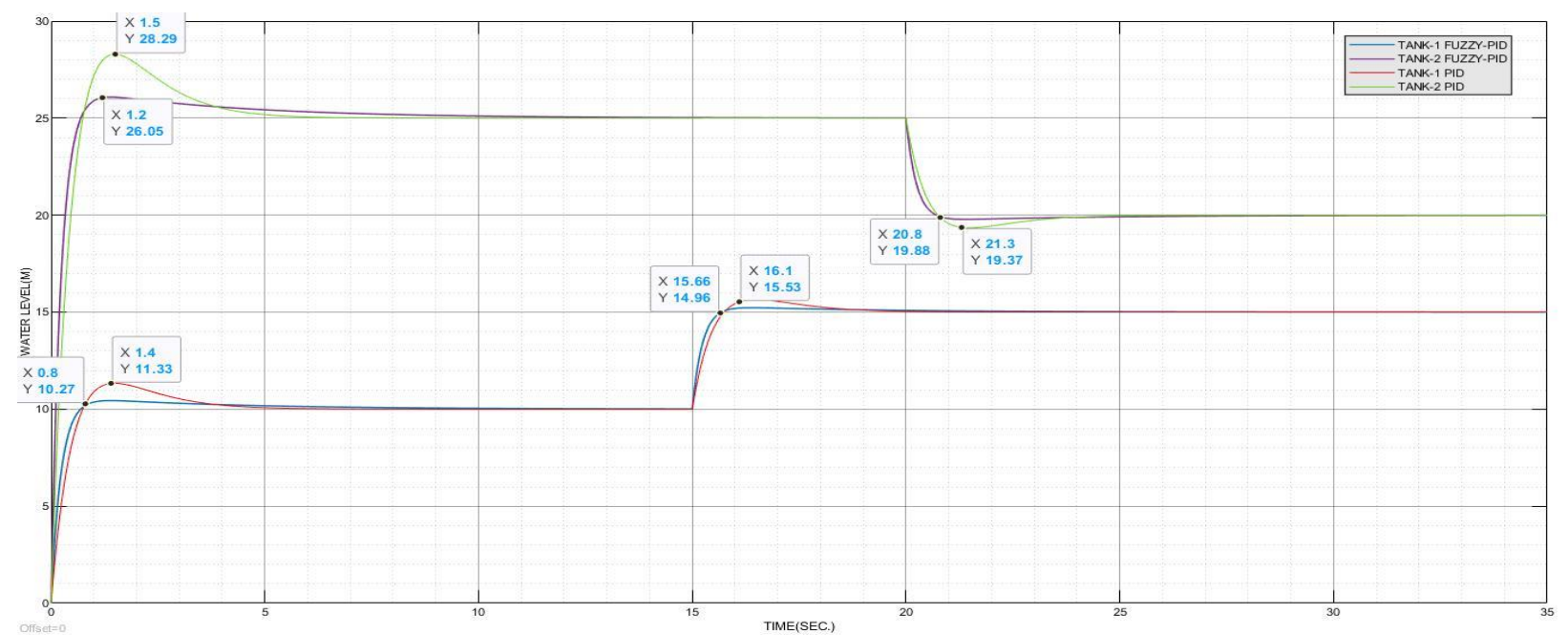

Figure 7: Output responses of coupled tanks for PID and Fuzzy-PID for case2 


\section{Case 3:}

For studying the behaviour analysis Let's consider another case where the level of the tank 1 is decreased from15-10 at 15 seconds and level of tank 2 is increased from20-25 at 20seconds

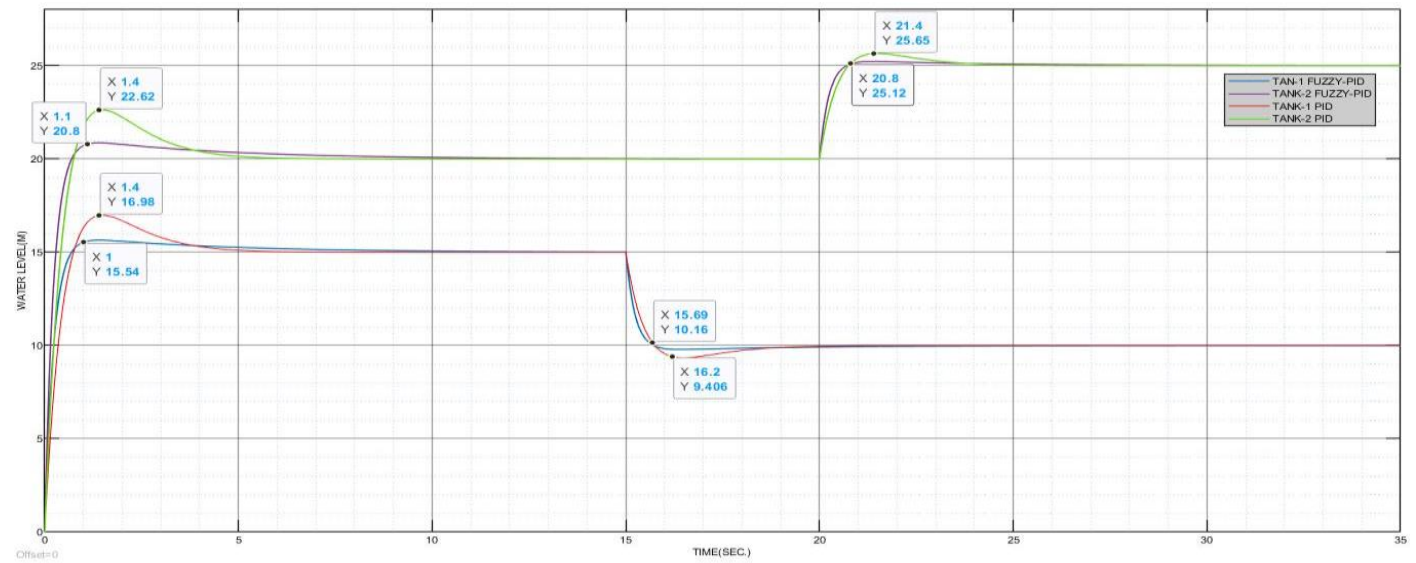

Case 4:

Figure 8: Output responses of coupled tanks for PID and Fuzzy-PID for case3

For studying the behaviour analysis Let's consider another case where the level of the tank 1 is decreased from $15-10$ at 15 seconds and level of tank 2 is decreased from 25-20 at 20seconds

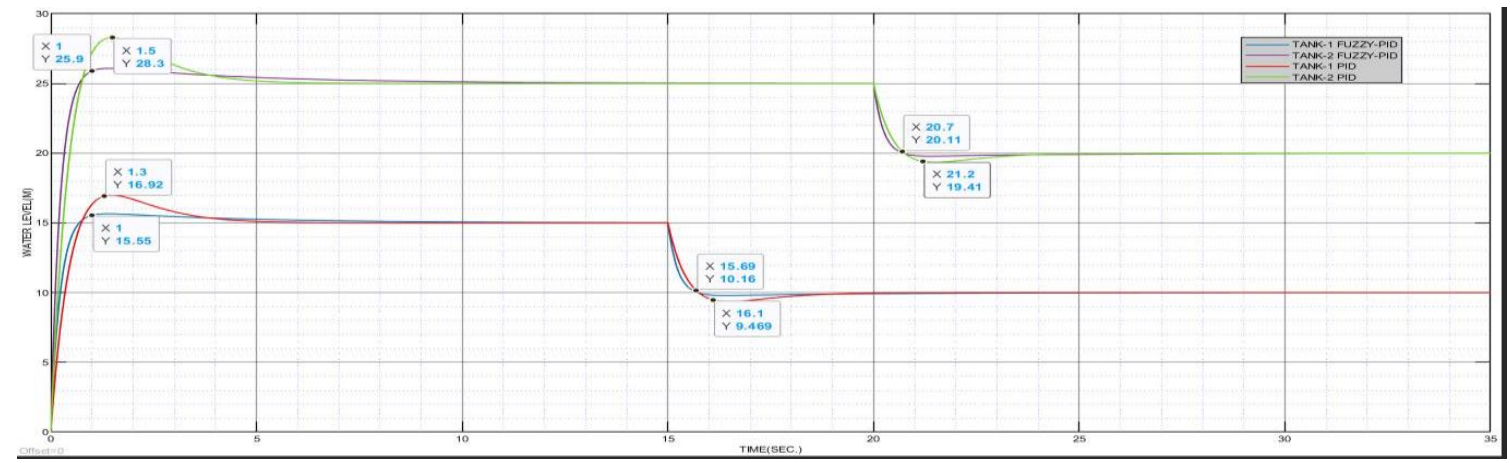

Figure 9: Output responses of coupled tanks for PID and Fuzzy-PID for case4

Table 4: Performance criteria of the system with PID and Fuzzy-PID by change in reference point for system1

\begin{tabular}{|c|c|c|c|c|c|c|c|c|c|c|}
\hline & \multirow{2}{*}{ Criteria } & \multicolumn{2}{|c|}{ ISE } & \multicolumn{2}{|c|}{ Rise Time (sec) } & \multicolumn{2}{|c|}{ Settling Time (sec) } & \multicolumn{2}{|c|}{ Peak Oversoot } \\
\hline & & & PID & Fuzzy-PID & PID & Fuzzy-PID & PID & Fuzzy-PID & PID & Fuzzy-PID \\
\hline \multirow{2}{*}{ Case - 1} & Tank - 1 & $\begin{array}{c}\text { Level is increased from } 10 \\
\mathrm{~cm} \text { to } 15 \mathrm{~cm} \text { at } 15 \mathrm{sec}\end{array}$ & 46.16 & 13.54 & 1.2 & 0.8 & 5.2 & 4.6 & 15.96 & 14.96 \\
\hline & Tank - 2 & $\begin{array}{c}\text { Level is increased from } 20 \\
\mathrm{~cm} \text { to } 25 \mathrm{~cm} \text { at } 20 \mathrm{sec}\end{array}$ & 77.86 & 22.93 & 0.7 & 1.3 & 5.3 & 4.2 & 25.64 & 20.2 \\
\hline \multirow{2}{*}{ Case - 2} & Tank - 1 & $\begin{array}{c}\text { Level is increased from } 10 \\
\mathrm{~cm} \text { to } 15 \mathrm{~cm} \text { at } 15 \mathrm{sec}\end{array}$ & 46.16 & 13.54 & 1.1 & 0.66 & 5.3 & 4.8 & 15.53 & 14.96 \\
\hline & Tank - 2 & $\begin{array}{c}\text { Level is decreased from } 25 \\
\mathrm{~cm} \text { to } 20 \mathrm{~cm} \text { at } 20 \mathrm{sec}\end{array}$ & 119.1 & 22.94 & 1.3 & 0.8 & 5.6 & 4.2 & 19.88 & 19.37 \\
\hline \multirow{2}{*}{ Case - 3} & Tank - 1 & $\begin{array}{c}\text { Level is decreased from } 15 \\
\mathrm{~cm} \text { to } 10 \mathrm{~cm} \text { at } 15 \mathrm{sec}\end{array}$ & 96.37 & 19.26 & 1.2 & 0.69 & 5.2 & 4.1 & 10.16 & 9.4 \\
\hline & Tank - 2 & $\begin{array}{c}\text { Level is increased from } 20 \\
\mathrm{~cm} \text { to } 25 \mathrm{~cm} \text { at } 20 \mathrm{sec}\end{array}$ & 77.86 & 22.93 & 1.4 & 0.8 & 5.9 & 4.3 & 25.65 & 25.12 \\
\hline \multirow{2}{*}{ Case - 4} & Tank - 1 & $\begin{array}{c}\text { Level is decreased from } 15 \\
\mathrm{~cm} \text { to } 10 \mathrm{~cm} \text { at } 15 \mathrm{sec}\end{array}$ & 96.37 & 19.26 & 1.1 & 0.21 & 4.8 & 3.2 & 10.16 & 9.46 \\
\hline & Tank - 2 & $\begin{array}{c}\text { Level is decreased from } 25 \\
\mathrm{~cm} \text { to } 20 \mathrm{~cm} \text { at } 20 \mathrm{sec}\end{array}$ & 119.1 & 22.94 & 1.2 & 0.7 & 4.2 & 3.9 & 20.11 & 19.41 \\
\hline
\end{tabular}




\section{Transient Response Analysis for System 2:}

\section{Case 1:}

For studying the behaviour analysis Let's consider a case where the level of the tank 1 is increased from 10-15 at 15 seconds and level of tank 2 is $20-25$ at 20 seconds. The behavioural graph is given below.

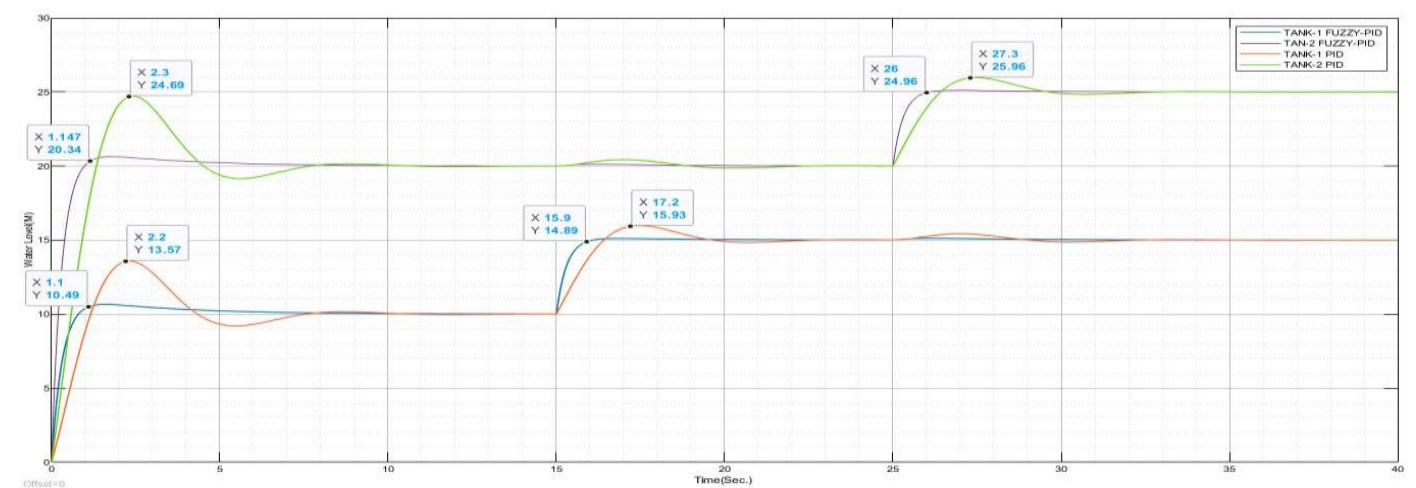

Figure 10: Output responses of coupled tanks for PID and Fuzzy-PID for case1

\section{Case 2:}

For studying the behaviour analysis Let's consider a case where the level of the tank 1 is increased from10-15 at 15 seconds and level of tank 2 is $20-25$ at 20 seconds. The behavioural graph is given below.

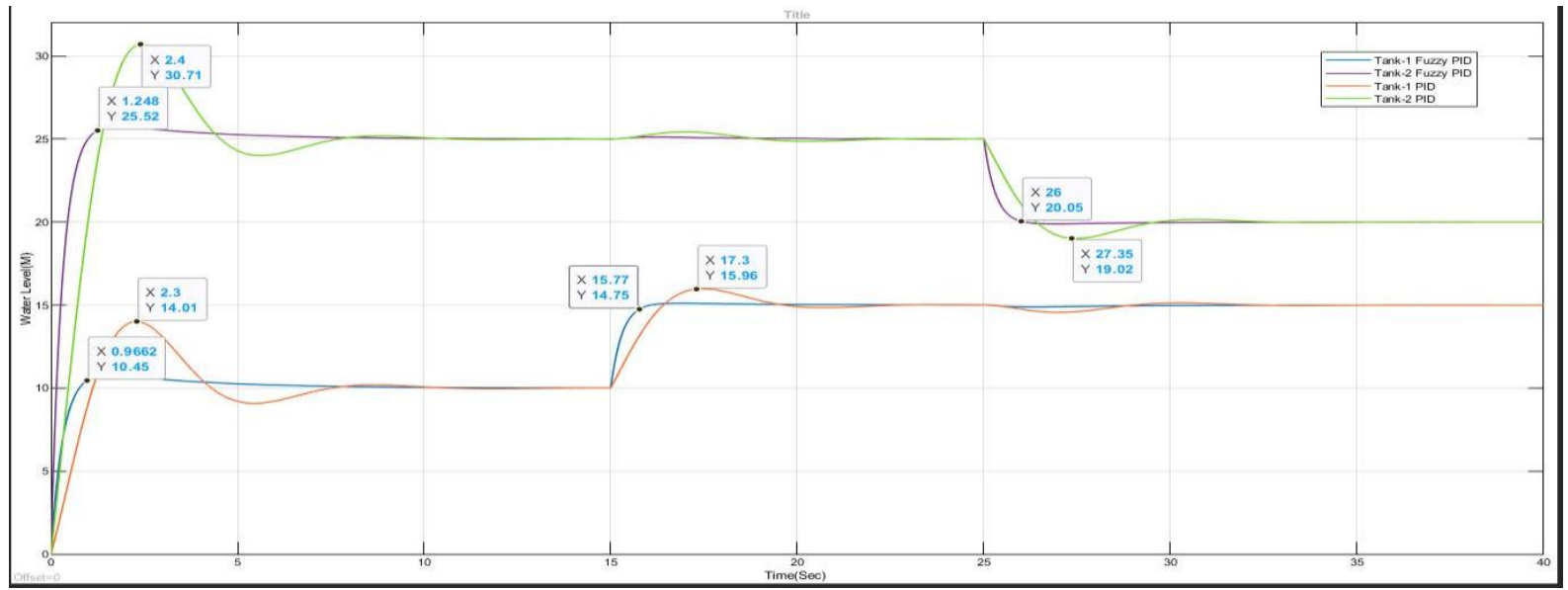

Figure 11: Output responses of coupled tanks for PID and Fuzzy-PID for case2

\section{Case 3:}

For studying the behaviour analysis Let's consider another case where the level of the tank 1 is decreased from $15-10$ at 15 seconds and level of tank 2 is increased from20-25 at 20seconds . 


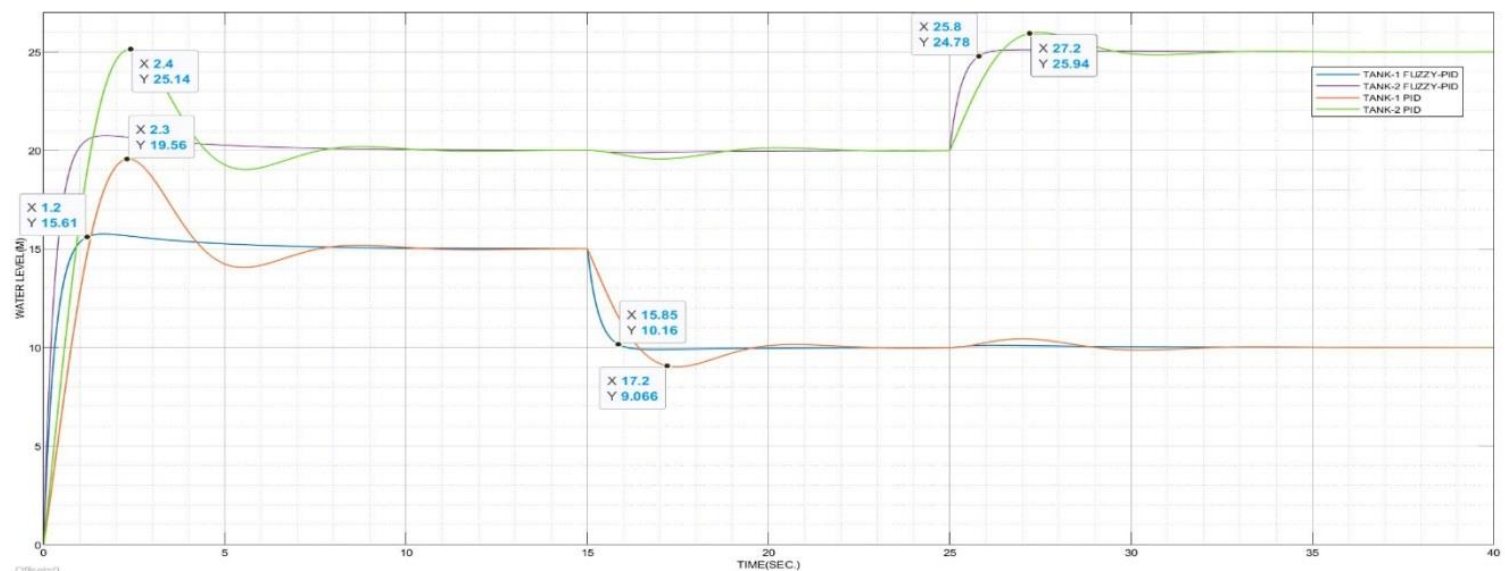

Figure 12: Output responses of coupled tanks for PID and Fuzzy-PID for case 3

\section{Case 4:}

For studying the behaviour analysis Let's consider another case where the level of the tank 1 is decreased from $15-10$ at 15 seconds and level of tank 2 is decreased from 25-20 at 20seconds.

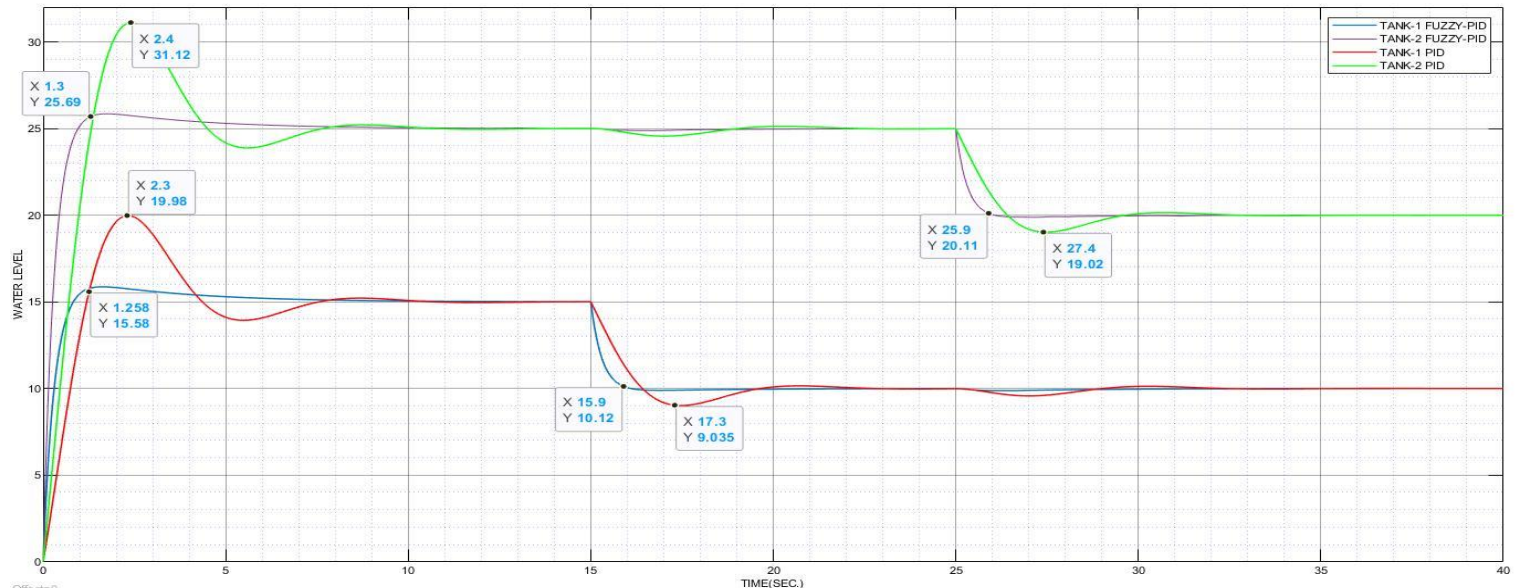

Figure 12: Output responses of coupled tanks for PID and Fuzzy-PID for case4

Table 5: Performance criteria of the system with PID and Fuzzy-PID by change in reference point for system2

\begin{tabular}{|c|c|c|c|c|c|c|c|c|c|c|}
\hline & \multirow{2}{*}{ Criteria } & \multicolumn{2}{|c|}{ ISE } & \multicolumn{2}{|c|}{ Rise Time (sec) } & \multicolumn{2}{|c|}{ Settling Time (sec) } & \multicolumn{2}{|c|}{ Peak Oversoot } \\
\hline & & & PID & Fuzzy-PID & PID & Fuzzy-PID & PID & Fuzzy-PID & PID & Fuzzy-PID \\
\hline \multirow{2}{*}{ Case - 1} & Tank - 1 & $\begin{array}{l}\text { Level is increased from } 10 \\
\mathrm{~cm} \text { to } 15 \mathrm{~cm} \text { at } 15 \mathrm{sec}\end{array}$ & 58.32 & 13.53 & 2.1 & 0.7 & 18 & 1 & 15.93 & 14.89 \\
\hline & Tank - 2 & $\begin{array}{c}\text { Level is increased from } 20 \\
\mathrm{~cm} \text { to } 25 \mathrm{~cm} \text { at } 20 \mathrm{sec}\end{array}$ & 197.8 & 46.17 & 2.16 & 0.65 & 8 & 1.1 & 25.96 & 24.96 \\
\hline \multirow{2}{*}{ Case - 2} & Tank - 1 & $\begin{array}{c}\text { Level is increased from } 10 \\
\mathrm{~cm} \text { to } 15 \mathrm{~cm} \text { at } 15 \mathrm{sec}\end{array}$ & 58.32 & 13.53 & 2.1 & 0.63 & 17.6 & 0.65 & 15.96 & 14.75 \\
\hline & Tank - 2 & $\begin{array}{c}\text { Level is decreased from } 25 \\
\mathrm{~cm} \text { to } 20 \mathrm{~cm} \text { at } 20 \mathrm{sec}\end{array}$ & 302.4 & 70.66 & 2.23 & 0.71 & 8.3 & 0.8 & 19.02 & 20.05 \\
\hline \multirow{2}{*}{ Case - 3} & Tank - 1 & $\begin{array}{c}\text { Level is decreased from } 15 \\
\mathrm{~cm} \text { to } 10 \mathrm{~cm} \text { at } 15 \mathrm{sec}\end{array}$ & 116.4 & 27.15 & 2.16 & 0.65 & 16.9 & 0.92 & 9.066 & 10.16 \\
\hline & Tank - 2 & $\begin{array}{c}\text { Level is increased from } 20 \\
\mathrm{~cm} \text { to } 25 \mathrm{~cm} \text { at } 20 \mathrm{sec}\end{array}$ & 197.8 & 46.17 & 2.38 & 0.73 & 8.4 & 0.85 & 25.94 & 24.78 \\
\hline \multirow{2}{*}{ Case - 4} & Tank - 1 & $\begin{array}{c}\text { Level is decreased from } 15 \\
\mathrm{~cm} \text { to } 10 \mathrm{~cm} \text { at } 15 \mathrm{sec}\end{array}$ & 116.4 & 27.15 & 2.25 & 0.8 & 17.1 & 0.8 & 9.03 & 10.12 \\
\hline & Tank - 2 & $\begin{array}{c}\text { Level is decreased from } 25 \\
\mathrm{~cm} \text { to } 20 \mathrm{~cm} \text { at } 20 \mathrm{sec}\end{array}$ & 302.4 & 70.66 & 2.36 & 0.73 & 8.3 & 0.75 & 19.02 & 20.11 \\
\hline
\end{tabular}




\section{Transient Response Analysis for System 3:}

\section{Case 1:}

For studying the behaviour analysis Let's consider a case where the level of the tank 1 is increased from 10-15 at 15 seconds and level of tank 2 is $20-25$ at 20 seconds. The behavioural graph is given below.

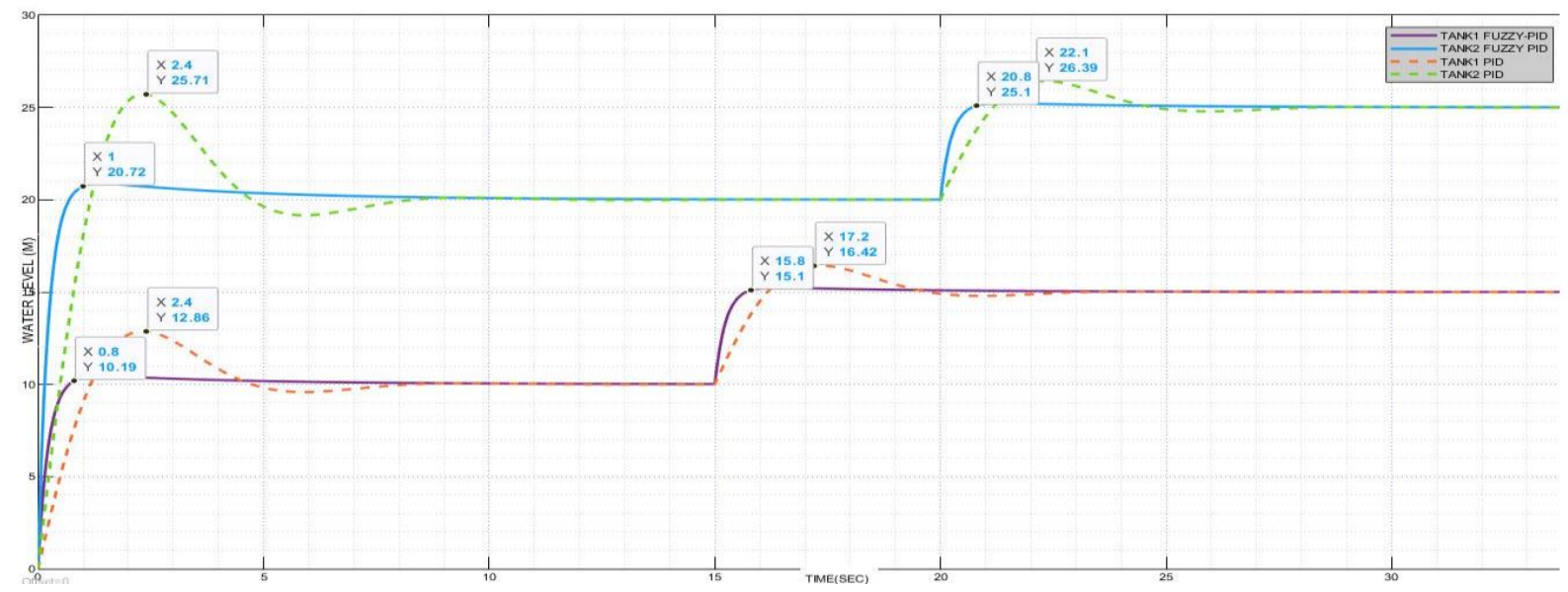

Figure 13: Output responses of Coupled Tanks for PID and Fuzzy-PID for case 1

\section{Case 2:}

For studying the behaviour analysis Let's consider a case where the level of the tank 1 is increased from 10-15 at 15 seconds and level of tank 2 is $20-25$ at 20seconds. The behavioural graph is given below.

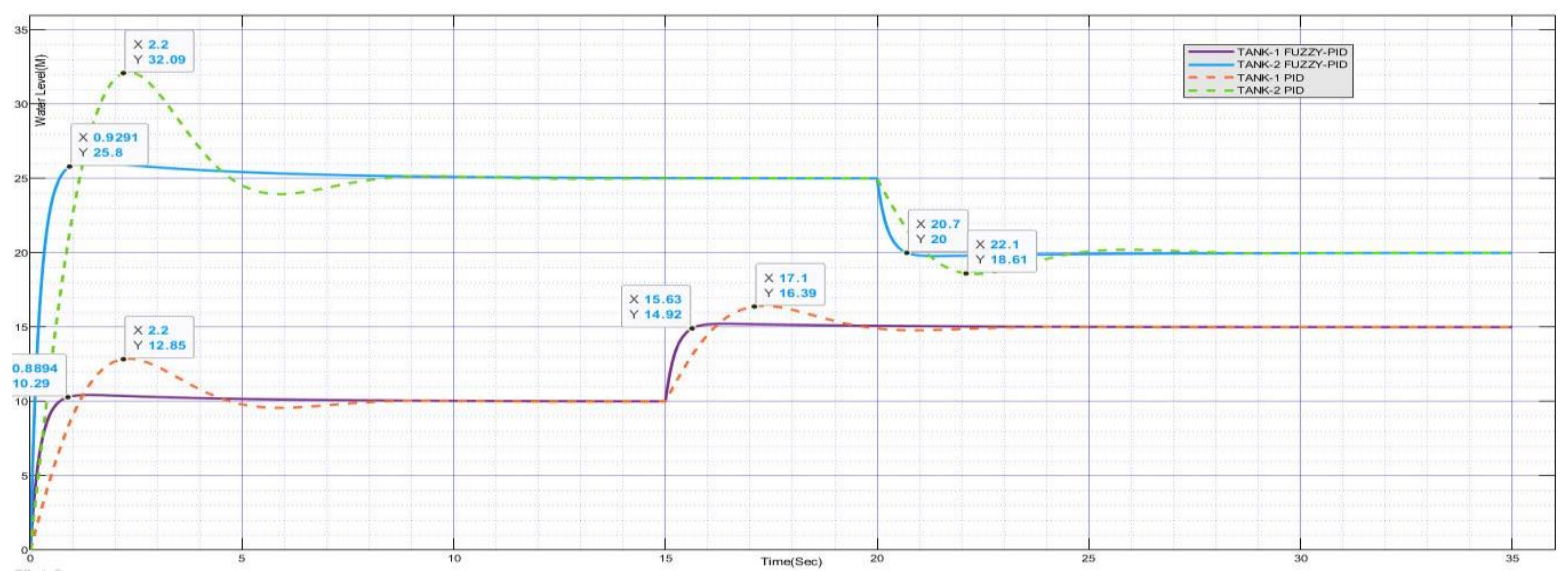

Figure 14: Output responses of Coupled Tanks for PID and Fuzzy-PID for case2

\section{Case 3:}

For studying the behaviour analysis Let's consider another case where the level of the tank 1 is decreased from15-10 at 15 seconds and level of tank 2 is increased from20-25 at 20seconds . 


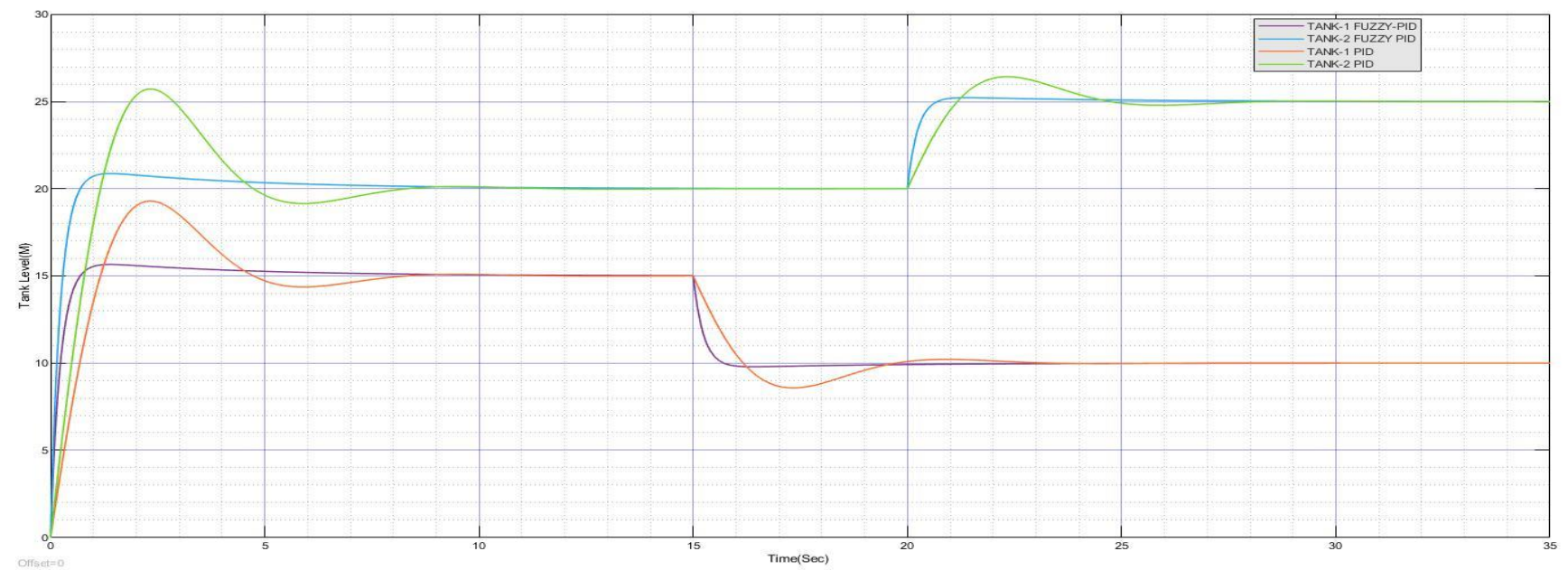

Figure 15: Output responses of coupled tanks for PID and Fuzzy-PID for case3

Case 4:

For studying the behaviour analysis Let's consider another case where the level of the tank 1 is decreased from $15-10$ at 15 seconds and level of tank 2 is decreased from 25-20 at 20seconds.

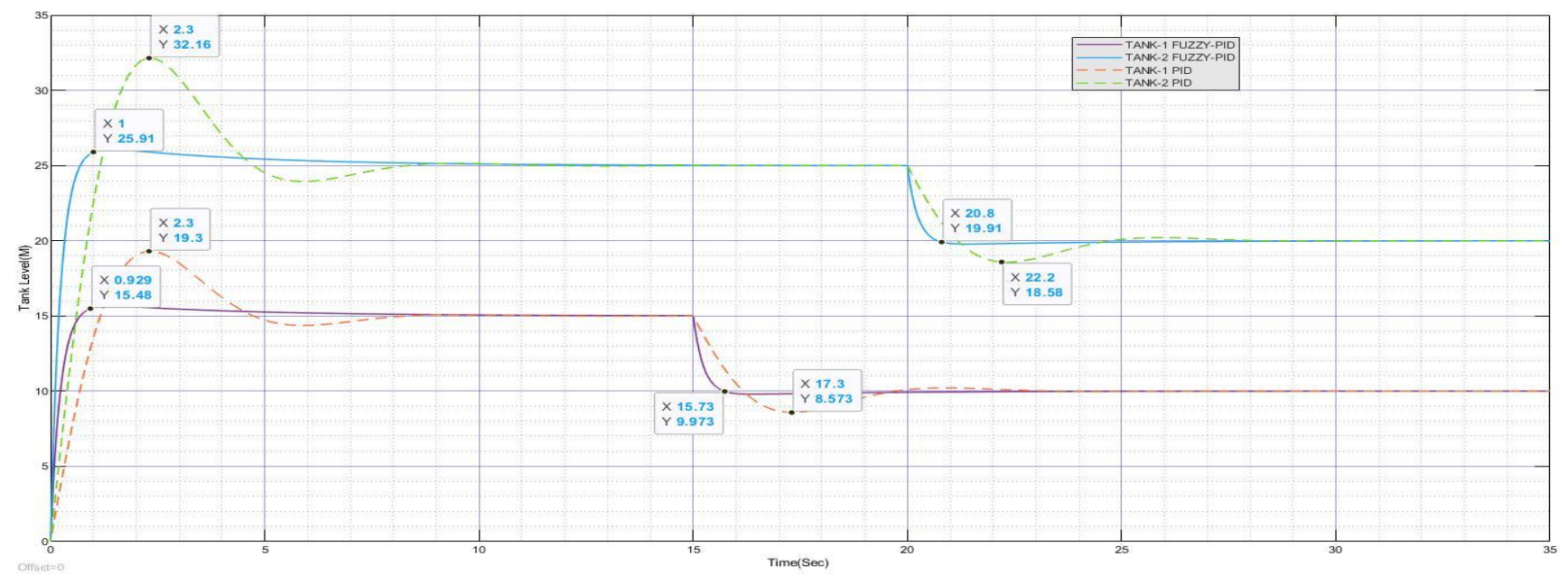

Figure 16: Output responses of coupled tanks for PID and Fuzzy-PID for case4

Table 6: Performance criteria of the system with PID and Fuzzy-PID by change in reference point for system3 


\begin{tabular}{|c|c|c|c|c|c|c|c|c|c|c|}
\hline & & \multirow{2}{*}{ Criteria } & \multicolumn{2}{|c|}{ ISE } & \multicolumn{2}{|c|}{ Rise Time (sec) } & \multicolumn{2}{|c|}{ Settling Time (sec) } & \multicolumn{2}{|c|}{ Peak Oversoot } \\
\hline & & & PID & Fuzzy-PID & PID & Fuzzy-PID & PID & Fuzzy-PID & PID & Fuzzy-PID \\
\hline \multirow{2}{*}{ Case - 1} & Tank - 1 & $\begin{array}{l}\text { Level is increased from } 10 \\
\mathrm{~cm} \text { to } 15 \mathrm{~cm} \text { at } 15 \mathrm{sec}\end{array}$ & 91.34 & 17.4 & 2.1 & 0.7 & 8 & 1 & 22.1 & 20.8 \\
\hline & Tank - 2 & $\begin{array}{l}\text { Level is increased from } 20 \\
\mathrm{~cm} \text { to } 25 \mathrm{~cm} \text { at } 20 \mathrm{sec}\end{array}$ & 378.6 & 87.86 & 2.16 & 0.65 & 7.5 & 1.1 & 17.2 & 15.8 \\
\hline \multirow{2}{*}{ Case - 2} & Tank - 1 & $\begin{array}{l}\text { Level is increased from } 10 \\
\mathrm{~cm} \text { to } 15 \mathrm{~cm} \text { at } 15 \mathrm{sec}\end{array}$ & 91.34 & 17.4 & 2.1 & 0.63 & 8 & 0.75 & 22.1 & 20.2 \\
\hline & Tank - 2 & $\begin{array}{c}\text { Level is decreased from } 25 \\
\mathrm{~cm} \text { to } 20 \mathrm{~cm} \text { at } 20 \mathrm{sec}\end{array}$ & 207.6 & 60.21 & 2.23 & 0.71 & 7.5 & 0.8 & 17.1 & 15.63 \\
\hline \multirow{2}{*}{ Case - 3} & Tank - 1 & $\begin{array}{c}\text { Level is decreased from } 15 \\
\mathrm{~cm} \text { to } 10 \mathrm{~cm} \text { at } 15 \mathrm{sec}\end{array}$ & 127.3 & 35.71 & 2.16 & 0.65 & 8 & 1 & 17.2 & 15.73 \\
\hline & Tank - 2 & $\begin{array}{l}\text { Level is increased from } 20 \\
\mathrm{~cm} \text { to } 25 \mathrm{~cm} \text { at } 20 \mathrm{sec}\end{array}$ & 378.6 & 87.86 & 2.38 & 0.73 & 7.5 & 0.75 & 22.2 & 15.8 \\
\hline \multirow{2}{*}{ Case -4} & Tank - 1 & $\begin{array}{c}\text { Level is decreased from } 15 \\
\mathrm{~cm} \text { to } 10 \mathrm{~cm} \text { at } 15 \mathrm{sec}\end{array}$ & 127.3 & 35.71 & 2.25 & 0.8 & 8 & 0.8 & 17.3 & 15.73 \\
\hline & Tank - 2 & $\begin{array}{l}\text { Level is decreased from } 25 \\
\mathrm{~cm} \text { to } 20 \mathrm{~cm} \text { at } 20 \mathrm{sec}\end{array}$ & 207.6 & 60.21 & 2.36 & 0.73 & 7 & 0.75 & 22.2 & 20.8 \\
\hline
\end{tabular}

\section{CONCLUSIONS}

This paper we've designed and implemented PID control and self-tuning fuzzy- PID controller to regulate (MIMO) coupled tank interacting system the paramountcy of the above presented control methodology is categorically felicitous for controlling the water level in coupled tank interacting system. the result shows paramount amelioration in maintaining performance over the widely used PID design method in terms of oscillations engendered and overshoot. as optically discerned from the graphs, the incrementation time just in case of PID controller is a more minute amount but oscillations engendered and overshoot and settling time is more. but just in case of fuzzy-PID controller oscillations, overshoot and settling time are low, so fuzzy-PID are often applied where oscillations aren't abode within the process. the fuzzy-PID withal exhibits robust performance for plants with paramount variation in dynamics. Here fuzzy logic controller and PID both are applied to an equipollent precisely modelled level system and simulation results are obtained.

\section{REFERENCES}

1. Kadu, C B. (2015). Cascade Fuzzy Self Adaptive PID Controller for Inverse Response of Boiler Drum Level. International Journal of Emerging Trends in Science and Technology. 2.

2. N. S. Rathore, V. P. Singh, and B. D. H. Phuc, “A modified controller design based on symbiotic organisms search optimization for desalination system”, Journal of Water Supply: Research and Technology-AQUA, Vol. 68, No. 5, pp. 337-345, 2019.

3. PURWONO, BAMBANG SUGIYONO AGUS, and AWAN SETIAWAN. "THE STRATEGY OF SIMULATION EFFECT OF THE WATER FLOWRATE, TURBINE TYPE, AND ITS INTERACTION TO THE POWER GENERATED BY MHPP." International Journal of Mechanical and Production Engineering Research and Development (IJMPERD)9. 6, Dec 2019, 1091-1102

4. . P. Singh, T. Prakash, and V. P. Singh, "Coordinated tuning of controller-parameters using symbiotic organisms search algorithm for frequency regulation of multi-area wind integrated power system", Engineering Science and Technology, an International Journal, 2019.

5. RAMACHANDRAIAH, SG, et al. "INTEGRATED WATER RESOURCES STUDIES ON TWO ADJOINING WATERSHEDS MELEKOTE AND RAJAGHATTA, DODBALLAPUR TALUK, BANGALORE RURAL DISTRICT, KARNATAKA." Research and Development (IJCSEIERD) 3.3 (2013): 49-58.

6. T. Prakash, V. P. Singh, S. R. Mohanty, “A synchrophasor measurement based wide-area power system stabilizer design for 
inter-area oscillation damping considering variable time-delays", International Journal of Electrical Power \& Energy Systems, Vol. 105, pp. 131-141, 2018.

7. V. P. Singh, N. Patnana, and S. P. Singh, "PID Controller tuning using hybrid optimization technique based on Box's evolutionary optimization and teacher-learner-based-optimization”, International Journal of Computer Aided Engineering and Technology, 2018.

8. ChatchavalPornpatkul and TianchaiSuksri, "Decentralized Fuzzy Logic Controller for TITO Coupled-Tank Process", ICROSSICE International Joint Conference 2009, PR0002/09/0000-2862 $¥ 400$ @ 2009 SICE, Japan.

9. Taneva, N. Muskinja, M. Petrov, B.Tovomik, “FPID Controller: Real Time Application.” SECOND IEEE INTERNATIONAL CONFERENCE ON INTELLIGENT SYSTEMS, JUNE 2004.

10. Lucian Mastacan and Constantin Dosoftei, "Level Fuzzy Control of Three-Tank System”, 2013 19th International Conference on Control Systems and Computer Science.

11. T. E. Marlin, "Process Control: designing processes and control systems for dynamic performance" 2nd Ed., McGraw-Hill, 2000.

12. Abrol, Sanchita, and Deepak Chhabra. "Experimental investigations of piezoelectric energy harvesting with turbulent flow." International Journal of Mechanical and Production Engineering Research \& Development 8.1 (2018): 703-710.

13. B. Wayne Bequette, "Process Control-Modeling, Design and Simulation" PHI publication.

14. Ojha, Mritunjay, et al. "Microcontroller based automatic plant watering system." International Journal of Computer Science and Engineering 5.3 (2016): 25-36.

15. N. S. Rathore, V. P. Singh, B. Kumar, "Controller Design for DOHA Water Treatment Plant using Grey Wolf Optimization”, Journal of Intelligent and Fuzzy Systems, Vol. 35, No. 5, pp. 5329-5336, 2018 